\title{
ANALISIS KETERSEDIAAN GARAM MENUJU PENCAPAIAN SWASEMBADA GARAM NASIONAL YANG BERKELANJUTAN (SUATU PENDEKATATAN MODEL DINAMIK)
}

\section{Analysis of Salt Availability Towards Sustainable National Salt Self- Sufficiency Achievement (A Dynamic Model Approach)}

\author{
Sri Dharmayanti ${ }^{1}$, Suharno ${ }^{1}$, Amzul Rifin ${ }^{2}$ \\ ${ }^{1}$ Mahasiswa Program Studi Agribisnis, Sekolah Pascasarjana, IPB \\ ${ }^{1}$ Ketua Komisi Pembimbing, Dosen pada Departemen Agribisnis, FEM - IPB \\ ${ }^{2}$ Anggota Komisi Pembimbing, Dosen pada Departemen Agribisnis, FEM - IPB \\ Email : dara_dharmayanti@yahoo.com
}

Diterima 2 Juli 2012 - Disetujui 4 Juni 2013

\begin{abstract}
ABSTRAK
Tercapainya swasembada garam nasional secara berkelanjutan merupakan kondisi ideal bagi Indonesia yang memiliki potensi alamiah sebagai produsen garam, namun hal tersebut hingga kini masih sulit terwujud. Kesenjangan antara kemampuan penyediaan dan kebutuhan garam masih cukup besar, sehingga impor masih terus dilakukan. Guna mempercepat terwujudnya swasembada garam nasional, di tahun 2011 pemerintah mengintervensi ketersediaan garam melalui kebijakan swasembada garam nasional. Terkait hal tersebut, maka penelitian ini bertujuan untuk (1) Mengukur ketercapaian keberlanjutan swasembada garam nasional dengan membangun model sistem ketersediaan garam nasional sebelum dan sesudah ada kebijakan swasembada, (2) Menyusun kebijakan alternatif agar swasembada garam nasional yang berkelanjutan dapat tercapai. Pendekatan dinamika sistem digunakan sebagai alat dalam menjawab tujuan penelitian. Dinamika ketersediaan garam nasional sebelum ada kebijakan swasembada dijadikan sebagai model dasar. Hasil validasi dengan menggunakan uji struktur dan uji kinerja model menunjukkan bahwa model yang dibangun valid. Hasil simulasi menunjukkan bahwa sebelum ada kebijakan, Indonesia belum dapat mencapai swasembada garam secara berkelanjutan baik garam konsumsi maupun garam industri. Sedangkan setelah ada kebijakan, hasil simulasi menunjukkan bahwa swasembada yang berkelanjutan baru dapat tercapai pada garam konsumsi. Swasembada garam industri dapat tercapai apabila kebijakan alternatif skenario 8 diterapkan, yaitu dengan melakukan peningkatan kuantitas dan kualitas garam rakyat, dan konversi garam secara bersamaan.
\end{abstract}

Kata Kunci: dinamika sistem, garam, ketersediaan, swasembada

\begin{abstract}
Achievement of sustainable national self-sufficiency in salt would be an ideal condition for Indonesia which has the natural potency as a salt producer; however, this condition has not realized yet. Gap between supply and demand capacities was still quite large, so that imports are still being conducted. In order to accelerate realization of salt national self-sufficiency in 2011 the government intervened in salt availability through national policy of salt self-sufficiency. In relation to this policy, this study aimed to (1) assess the achievement of sustainable salt self-sufficiency to build a model of system availability nationwide salt before and after a policy of self-sufficiency and (2) Develop an alternative policy so salt national sustainable self-sufficiency can be achieved a system dynamic approach was used as a tool to answer the research objectives. Dynamics of salt availability before a policy of national self-sufficiency served as the based model. Results of validation using a model structure test and performance test showed that the constructed model was valid. Simulation results showed before any policy, Indonesia has not been able to achieved sustainable salt self-sufficiency and salt industrial consumption. While once there was a policy, the simulation results showed that the new sustainable self-sufficiency can be achieved on salt consumption. Salt industrial self-sufficiency can be achieved if the alternative policy scenario 8 is applied, i.e., by increasing salt farming quantity and quality and salt conversion simultaneously.
\end{abstract}

Keywords: system dynamics, salt, availability, self-sufficiency 


\section{PENDAHULUAN}

Garam memiliki peran strategis yaitu sebagai bahan pokok bagi kebutuhan konsumsi dan juga merupakan bahan baku berbagai industri. Kebutuhan konsumsi antara lain digunakan untuk konsumsi rumah tangga, industri makanan, industri minyak goreng, industri pengasinan dan pengawetan ikan, sedangkan kebutuhan industri antara lain untuk industri perminyakan, tekstil dan penyamakan kulit, industri pakan ternak, industri chlor alkali (CAP), industri farmasi (Deperin 2009).

Indonesia memiliki potensi alam sebagai penghasil garam. Secara geografis, Indonesia kaya akan sumber daya mineral. Indonesia juga merupakan salah satu negara maritim terbesar dunia dengan luas laut 70 persen dari total luas wilayah Indonesia dan memiliki garis pantai terpanjang kedua di dunia yaitu sepanjang 95181 $\mathrm{km}$. Namun dari lahan pesisir Indonesia yang ada, tidak seluruhnya dapat digunakan sebagai lahan tambak garam. Berdasarkan Balitbang KKP (2012) hanya 34 ribu hektar lahan pesisir di Indonesia yang memenuhi kriteria teknis untuk digunakan sebagai lahan tambak garam. Dari luasan tersebut, hingga saat ini baru sekitar 60 persen yang telah dimanfaatkan sebagai lahan tambak garam produktif.

Garam nasional dipasok oleh produksi PT Garam dan produksi garam rakyat. Meskipun keduanya menggunakan metode penguapan air laut oleh bantuan cahaya matahari (solar evaporation), namun terdapat perbedaan kualitas garam yang dihasilkan. Garam rakyat menghasilkan kualitas yang lebih rendah (kandungan $\mathrm{NaCl}$ di bawah 90 persen) daripada garam yang dihasilkan oleh PT Garam. Perbedaaan tersebut disebabkan penguapan yang dilakukan oleh PT Garam menggunakan lahan yang lebih luas dan waktu penguapan yang lebih lama. Sementara di sisi permintaan, kebutuhan garam memiliki kriteria kualitas yang spesifik. Untuk kebutuhan konsumsi, dibutuhkan garam dengan kandungan $\mathrm{NaCl} 85$ hingga 97 persen, sedangkan untuk kebutuhan industri dibutuhkan garam dengan kandungan 90 hingga 99,8 persen $\mathrm{NaCl}$. Kriteria tersebut tampak kontras dengan kualitas produksi garam nasional dengan kandungan $\mathrm{NaCl}$ masih dibawah 90 persen. Hal ini mengindikasikan terdapat senjang kualitas antara kriteria yang dibutuhkan dan kemampuan dalam negeri dalam penyediaan garam.
Di sisi kuantitas, produksi yang dihasilkan oleh lahan tambak garam produktif Indonesia juga belum dapat memenuhi tingginya kebutuhan. Pada cuaca normal, kemampuan produksi relatif stabil. Data produksi garam tahun 2001 hingga tahun 2009 menunjukan rata-rata produksi sebesar 1,2 juta ton per tahun. Sedangkan pada cuaca ekstrim dengan curah hujan tinggi produksi bisa merosot bahkan hingga mencapai 30 ribu ton saja (data tahun 2010). Berbeda dengan kebutuhan garam nasional yang memiliki tren yang cenderung meningkat dari tahun ke tahun. Peningkatan kebutuhan garam dipengaruhi besarnya pertumbuhan penduduk dan pertumbuhan industri nasional. Berdasarkan data Kementerian Kelautan dan Perikanan (2012), secara kuantitas rata-rata kebutuhan garam nasional pada tahun 2008-2011 sebesar 3 juta ton, yaitu 1,2 juta ton untuk garam konsumsi dan 1,8 juta ton untuk garam industri.

Kesenjangan baik dari sisi kuantitas maupun kualitas ini menjadi pintu bagi masuknya garam impor mengingat keberadaan garam sebagai komoditas bahan pokok dan tidak memiliki produk pengganti (unsubstitued). Keberadaan garam impor dipadu dengan lemahnya bargaining position petambak garam lokal pada akhirnya mempengaruhi pasar garam nasional. Kondisi ini mengakibatkan semakin kuatnya posisi garam impor dan sebaliknya pergaraman nasional menjadi semakin lesu. Ketergantungan terhadap garam impor yang semakin tinggi pada akhirnya mendorong pemerintah untuk menggagas kebijakan swasembada garam nasional di tahun 2011.

Terwujudnya swasembada garam nasional yang berkelanjutan mengandung arti penting bagi Indonesia. Dengan tercapainya swasembada tentu akan menghemat pengeluaran negara, membangkitkan geliat usaha garam lokal dan bahkan dapat menjadi sumber devisa negara. Tercapainya swasembada garam juga akan mendorong tumbuh dan berkembangnya sektor industri nasional. Dengan dilatarbelakangi oleh peran penting swasembada, maka penelitian ini bermaksud untuk mengukur ketercapaian swasembada garam nasional secara berkelanjutan.

Pengukuran ketercapaian keberlanjutan swasembada garam nasional yang dilakukan dalam penelitian ini akan didekati melalui pendekatan dinamika sistem ketersediaannya. Ketersediaan menggambarkan sejumlah barang yang tersedia dalam suatu negara. Besarnya ketersediaan merupakan selisih antara penyediaan 
dan kebutuhan. Adapun sumber penyediaan antara lain produksi, cadangan dan impor. Sementara kebutuhan menggambarkan besarnya permintaan terhadap komoditas tersebut. Ketersediaan dapat menggambarkan kemampuan suatu negara dalam memenuhi kebutuhannya sendiri (swasembada). Konsep ketersediaan yang didekati dengan pendekatan sistem dapat memberikan gambaran yang utuh mengenai objek yang diteliti. Dimana sistem merupakan gabungan komponen yang teratur yang memiliki kontribusi terhadap perilaku sistem dan dipengaruhi karena berada di dalam sistem (Ristono, 2011). Penelitian Georgiadis (2004), Somantri dan Machmud (2006), Irawan (2005), Somantri dan Thahir (2007), Harmini et al., (2011) dan Nurmalina (2007) melakukan pendekatan dinamika sistem ketersediaan untuk menelaah objek kajiannya. Pendekatan sistem umumnya dimulai dengan dilakukannya identifikasi terhadap adanya sejumlah faktor penting yang ada sehingga menghasilkan suatu sistem yang dianggap efektif, kemudian memodelkannya dalam suatu model kuantitatif untuk membantu memberikan keputusan secara rasional. Model yang dibangun berhubungan erat dengan perilaku (behavior) dinamik sistem yang kompleks. Sehingga pendekatan ini dianggap mampu mengakomodir keterkaitan antar komponen dan kedinamisan sistem sehingga mampu memberikan gambaran proyeksi di masa mendatang. Dalam kaitannya dengan penelitian ini, proyeksi akan membantu pengukuran ketercapaian keberlanjutan swasembada garam nasional di masa mendatang.

Ketercapaian keberlanjutan swasembada garam nasional memerlukan intervensi pemerintah. Dalam penelitian Wirjodirdjo (2004) menjelaskan bahwa strategi yang dapat dilakukan untuk mengurangi ketergantungan Indonesia terhadap garam impor adalah dengan melakukan intensifikasi lahan, ekstensifikasi lahan, dan peningkatan kualitas garam rakyat. Ketiga hal tersebut sejalan dengan instrumen yang digunakan dalam kebijakan swasembada garam nasional. Sejauh mana intervensi ini akan berhasil perlu dilihat secara seksama.

Berdasarkan uraian tersebut maka penelitian ini bertujuan untuk:

1. Mengukur ketercapaian keberlanjutan swasembada garam nasional dengan membangun model sistem ketersediaan garam nasional sebelum dan sesudah ada kebijakan swasembada
2. Menyusun kebijakan alternatif agar swasembada garam nasional yang berkelanjutan dapat tercapai

\section{METODE PENELITIAN}

\section{Metode Pengumpulan Data}

Jenis data yang digunakan pada penelitian ini adalah data sekunder yang terkait dengan penyediaan dan kebutuhan garam nasional dari tahun 2001 hingga 2012. Data sekunder yang digunakan berupa data jumlah fisik produksi garam, kualitas garam yang dihasilkan, luas lahan, tren produktivitas, besar kebutuhan garam, impor garam, populasi penduduk dan konsumsi garam per kapita. Data diperoleh dari Kementerian Kelautan dan Perikanan, Kementerian Perindustrian, PT. Garam, Badan Pusat Statistik, dan hasil-hasil publikasi terkait dengan penelitian. Pengambilan data dilakukan sejak November 2012 hingga Januari 2013.

\section{Metode Analisa Data}

Tujuan penelitian ini akan dijawab melalui pendekatan dinamika sistem dengan penyusunan model dinamika sistem ketersediaan garam nasional. Tujuan penelitian akan dijawab melalui 4 tahap, yaitu membangun model ketersediaan garam nasional, validasi, simulasi dan eksekusi skenario alternatif terhadap model dengan menggunakan software Powersim studio. Tahun dasar yang digunakan dalam pemodelan adalah tahun 2008 (sebelum ada kebijakan). Simulasi pemodelan dilakukan untuk menganalisis pergaraman nasional sebelum dan sesudah ada kebijakan (tahun 2008 hingga tahun 2025).

\section{Pembangunan Model}

Sistem ketersediaan garam nasional yang dibangun mengakomodir ketersediaan garam konsumsi dan garam industri. Model dibangun atas 4 submodel utama yaitu (1) Submodel penyediaan garam konsumsi, (2) Submodel kebutuhan garam konsumsi, (3) Submodel penyediaan garam industri dan (4) Submodel kebutuhan garam industri.

\section{Validasi Model}

Variabel yang akan divalidasi secara kinerja model adalah variabel produksi garam konsumsi, kebutuhan garam konsumsi, impor garam industri dan kebutuhan garam industri. Variabel-variabel tersebut merupakan perwakilan dari setiap 
submodel. Tahun validasi kinerja model adalah tahun 2008-2010. Uji validasi yang digunakan yaitu Root Mean Square Percentage Error (RMSPE), Absolute Mean Error (AME) dan Absolute Variance Error(AVE). Batas penyimpangan dari kriteria-kriteria di atas yang dapat diterima adalah 5 persen.

\section{Simulasi Kebijakan}

Dalam penelitian ini dilakukan 2 jenis simulasi terhadap model dinamika sistem ketersediaan garam nasional, yaitu simulasi setelah ada kebijakan pemerintah dan simulasi kebijakan alternatif. Simulasi setelah ada kebijakan mengacu pada indikator capaian swasembada, yaitu sebagai berikut:

1. Pelaksanaan PUGAR diasumsikan mampu meningkatkan produktivitas garam rakyat melalui kebijakan intensifikasi lahan dari 60 ton/ha/tahun menjadi 84 ton/ha/tahun untuk menghasilkan peningkatan garam konsumsi.

2. Konversi surplus garam konsumsi menjadi garam industri

3. Pelaksanaan kebijakan swasembada garam diasumsikan mampu memproduksi garam industri dengan indikator capaian berdasarkan Tabel 1.

Simulasi kebijakan pertama menggunakan 5 skenario sebagai berikut:

1. Skenario 1 : 60 persen dari indikator tercapai.

2. Skenario 2 : 80 persen dari indikator tercapai.

3. Skenario $3: 100$ persen dari indikator tercapai (pencapaian produktivitas ekstensifikasi di batas bawah range indikator).
4. Skenario $4: 100$ persen dari indikator tercapai (pencapaian produktivitas ekstensifikasi di nilai tengah range indikator).

5. Skenario 5: 100 persen dari indikator tercapai (pencapaian produktivitas ekstensifikasi di batas atas range indikator).

Sedangkan simulasi kebijakan yang kedua dilakukan agar diperoleh alternatif kebijakan yang lebih baik dibandingkan kebijakan yang telah ada guna mempercepat terwujudnya swasembada garam nasional yang berkelanjutan. Skenario alternatif kebijakan yang digunakan adalah :

1. Skenario 6 : Skenario 4 dengan koreksi peningkatan produktivitas PUGAR menjadi sebesar 97 ton per hektar (mengacu pada capaian produktivitas PUGAR tahun 2012).

2. Skenario 7 : Skenario 6 dengan asumsi seluruh pengusahaan garam rakyat terintervensi PUGAR.

3. Skenario 8 : Skenario 7 dengan reduksi konsumsi garam untuk rumah tangga mengikuti rekomendasi salt intake WHO dan peningkatan kualitas garam yang dihasilkan oleh garam rakyat sehingga dapat digunakan langsung untuk memenuhi kebutuhan garam industri.

\section{HASIL DAN PEMBAHASAN}

\section{Sistem Ketersediaan Garam Nasional}

Untuk mencapai swasembada garam nasional yang berkelanjutan berbagai kebijakan dan program dicanangkan oleh pemerintah. Adapun besar penyediaan garam ditentukan oleh besarnya kebutuhan garam baik garam konsumsi

Tabel 1. Target Indikator Capaian Ekstensifikasi Lahan, 2012-2015.

Table 1. Achivable Indicators of Land Extensification, 2012-2015.

\begin{tabular}{lcrrrr}
$\quad$\begin{tabular}{l} 
Indikator Capaian/ \\
\multicolumn{1}{c}{ Indicators of Achievement }
\end{tabular} & Unit & $\mathbf{2 0 1 2}$ & $\mathbf{2 0 1 3}$ & $\mathbf{2 0 1 4}$ & $\mathbf{2 0 1 5}$ \\
\hline Lahan baru terolah / New arable land & Ha & 1,315 & 3,945 & 5,698 & 7,890 \\
Produktivitas/ Productivity & ton/ha & 75 & $75-100$ & $75-125$ & $100-125$ \\
$\begin{array}{l}\text { Pemenuhan kebutuhan garam industri/ } \\
\text { Fulfilling the needs of industrial salt }\end{array}$ & $\%$ & & 30 & 59 & 95 \\
\hline
\end{tabular}

Sumber : Kemenko Perekonomian, 2012/Source: Coordinating Minister for Economic Affairs, 2012. 
maupun industri secara nasional. Kebutuhan garam konsumsi berdasarkan Deperin (2009) ditentukan oleh 3 kelompok pengguna garam terbesar yaitu rumah tangga, industri aneka pangan dan pengasinan ikan, sedangkan kebutuhan garam industri ditentukan oleh besarnya kebutuhan industri chlor alkali, industri pengeboran minyak dan industri lainnya. Hubungan antar komponen dijelaskan dalam diagram sebab akibat sistem ketersediaan garam nasional (Gambar 1).

\section{Model Ketersediaan Garam Nasional Indonesia}

Pengembangan model dinamika sistem dalam bentuk diagram alir (Gambar 2) ditujukan untuk dapat menganalisis ketersediaan garam untuk mengukur ketercapaian swasembada garam nasional yang berkelanjutan. Submodel dibangun dari variabel-variabel tekait yang mengacu pada penelitian-penelitian sebelumnya. Secara umum pembangunan submodel produksi baik pada garam rakyat maupun PT Garam dibangun oleh variabel luas lahan, jumlah hari panen dan produktivitas. Variabel luas lahan dimasukkan sebagai variabel produksi garam, hal tersebut sesuai dengan penelitian Wirjodirdjo (2004), Rachman (2011) dan Aligori (2013). Sedangkan jumlah hari panen berdasarkan Aligori (2013) merupakan variabel signifikan pada produksi garam. Jumlah hari panen bertujuan untuk mengakomodir faktor curah hujan atau cuaca dalam proses produksi garam. Produktivitas lahan tambak garam dimasukan sebagai faktor produksi merujuk pada penelitian Wirjodirdjo (2004). Perbedaan antara produksi garam rakyat dan PT Garam terletak pada tingkat produktivitas rata-rata dan luas lahan yang dimiliki. Penyediaan garam nasional dipasok oleh produksi garam rakyat, produksi PT Garam dan cadangan yang bersumber dari surplus ketersediaan tahun lalu.

Beberapa asumsi dasar yang mendasari model antara lain :

1. Data dasar yang digunakan untuk awal simulasi adalah data tahun 2008 dengan pertimbangan bahwa tahun tersebut kondisi cuaca dalam keadaan normal dan belum ada intervensi kebijakan swasembada.

2. Tingkat laju peningkatan luas lahan tambak garam milik PT Garam adalah sebesar 0,92 persen per tahun (diolah dari data PT Garam, 2012).

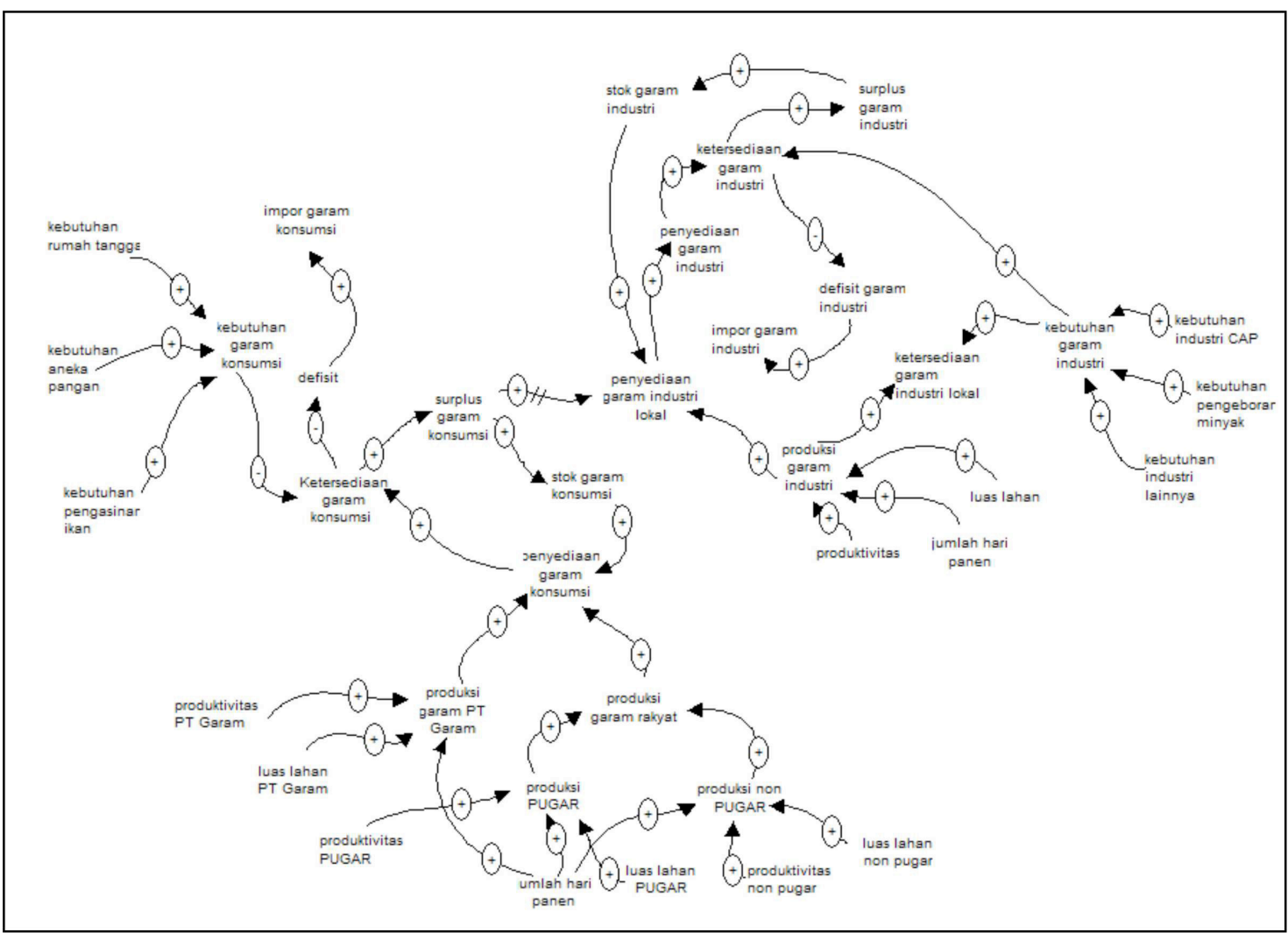

Gambar 1. Diagram Sebab Akibat Sistem Ketersediaan Garam Nasional

Figure 1. Causal Loop Diagram of National Salt Availability System 


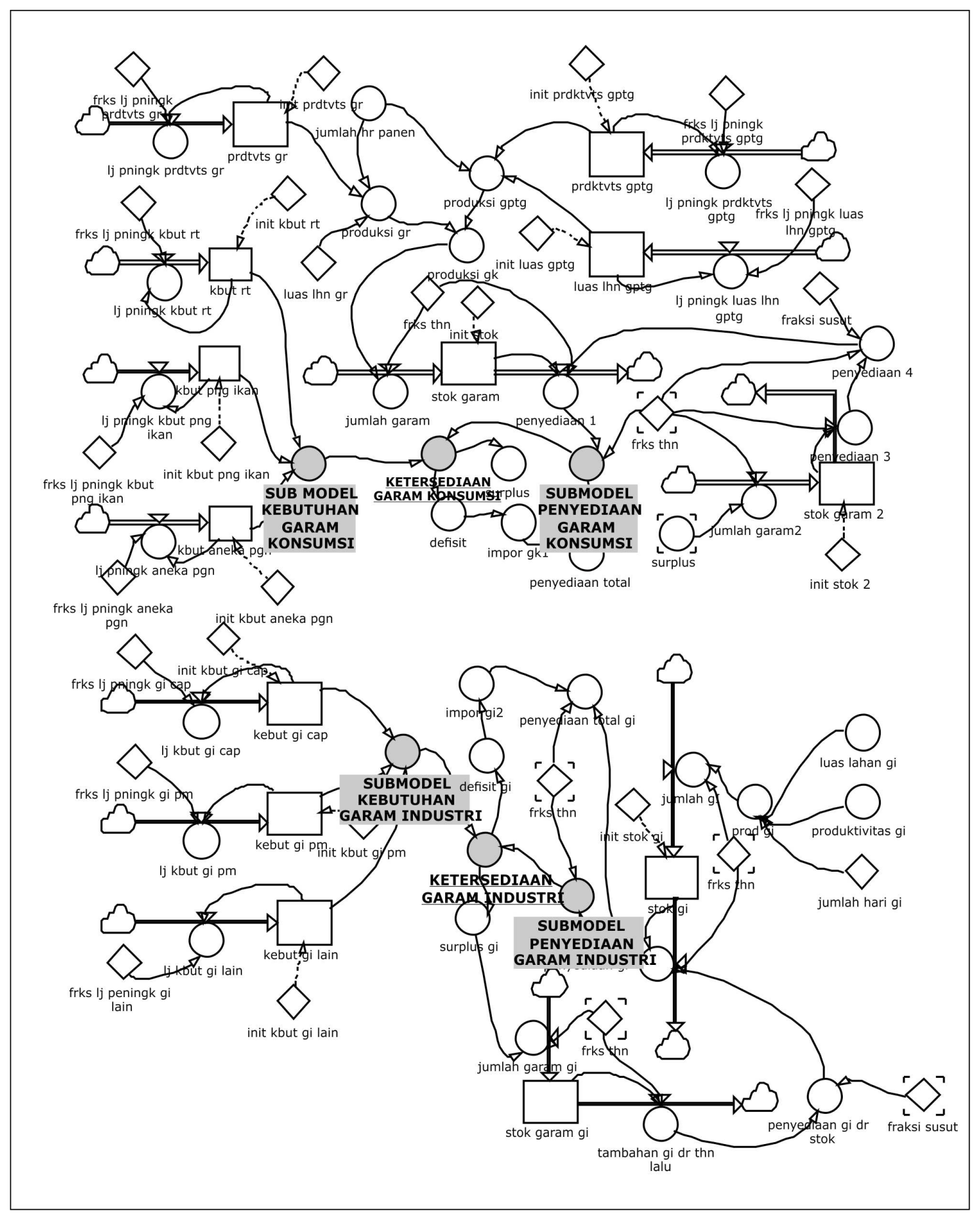

Gambar 2. Diagram Alir Model Sistem Ketersediaan Garam Nasional Figure 2. Stock and Flow Diagram of National Salt Availability Model

3. Tingkat laju peningkatan produktivitas garam oleh PT Garam sebesar 4,76 persen per tahun (diolah dari data PT Garam, 2012).

4. Tingkat laju peningkatan produktivitas garam rakyat sebesar 3,43 persen per tahun (diolah dari data Kemenperin, 2012).

5. Jumlah hari panen pada cuaca normal adalah 4 hingga 4,5 bulan (Kemenperin, 2011)

6. Jumlah hari panen pada cuaca ekstrim adalah 16 hari (Kemenperin, 2011)

7. Tingkat pertumbuhan kebutuhan garam konsumsi untuk aneka pangan 6,35 persen per tahun (diolah dari data Kemenperin, 2012) 
8. Tingkat pertumbuhan kebutuhan garam konsumsi untuk rumah tangga 1,97 persen per tahun (diolah dari data Kemenperin, 2012)

9. Tingkat pertumbuhan kebutuhan garam konsumsi untuk pengasinan ikan 2,67 persen per tahun (diolah dari data Kemenperin, 2012)

10. Tingkat pertumbuhan kebutuhan garam industri untuk industri chlor alkali 1,22 persen per tahun (diolah dari data Kemenperin, 2012)

11. Tingkat pertumbuhan kebutuhan garam industri untuk industri chlor alkali 1,22 persen per tahun (diolah dari data Kemenperin, 2012)

12. Tingkat pertumbuhan kebutuhan garam industri untuk industri pengeboran minyak 0,3 persen per tahun (diolah dari data Kemenperin, 2012)

13. Tingkat pertumbuhan kebutuhan garam industri untuk industri lainnya 2,78 persen per tahun (diolah dari data Kemenperin, 2012)

14. Persentase penyusutan surplus garam dari tahun lalu adalah sebesar 25 persen (Kemenperin, 2011)

\section{Validasi Model}

Validasi struktur dilakukan langsung oleh perangkat lunak. Dari hasil pengujian tersebut, tidak ditemukan inkonsistensi dalam penggunaan dimensi. Sedangkan hasil uji validitas kinerja model dengan menggunakan RMSPE , AME dan
AVE membandingkan hasil kinerja model dengan data empiris yang ada, hasilnya menunjukkan penyimpangan tidak melebihi 5 persen. Sehingga model valid baik secara struktur maupun kinerja model.Tingkat laju peningkatan luas lahan tambak garam milik PT Garam adalah sebesar 0,92 persen per tahun (diolah dari data PT Garam, 2012).

15. Tingkat laju peningkatan produktivitas garam oleh PT Garam sebesar 4,76 persen per tahun (diolah dari data PT Garam, 2012).

16. Tingkat laju peningkatan produktivitas garam rakyat sebesar 3,43 persen per tahun (diolah dari data Kemenperin, 2012).

17. Jumlah hari panen pada cuaca normal adalah 4 hingga 4,5 bulan (Kemenperin, 2011)

18. Jumlah hari panen pada cuaca ekstrim adalah 16 hari (Kemenperin, 2011)

19. Tingkat pertumbuhan kebutuhan garam konsumsi untuk aneka pangan 6,35 persen per tahun (diolah dari data Kemenperin, 2012)

20. Tingkat pertumbuhan kebutuhan garam konsumsi untuk rumah tangga 1,97 persen per tahun (diolah dari data Kemenperin, 2012)

21. Tingkat pertumbuhan kebutuhan garam konsumsi untuk pengasinan ikan 2,67 persen per tahun (diolah dari data Kemenperin, 2012)

22. Tingkat pertumbuhan kebutuhan garam industri untuk industri chlor alkali 1,22

Tabel 2. Hasil Uji Validitas Kinerja Model Sistem Ketersediaan Garam Nasional.

Table 2. Results of Validity Test For the Performance of National Salt Availability System Model.

\begin{tabular}{cccccc}
\hline & & \multicolumn{2}{c}{ Persentase Hasil Uji Validitas / Percentage Validity Test Results (\%) } \\
\cline { 3 - 6 } No & $\begin{array}{c}\text { Kriteria/ } \\
\text { Criteria }\end{array}$ & $\begin{array}{c}\text { Produksi } \\
\text { garam konsumsi/ } \\
\text { Salt Production } \\
\text { for Consumption }\end{array}$ & $\begin{array}{c}\text { Kebutuhan } \\
\text { garam } \\
\text { konsumsi/ } \\
\text { Salt Needs of } \\
\text { Consumption }\end{array}$ & $\begin{array}{c}\text { Impor } \\
\text { garam industri/ } \\
\text { Salt Impor for } \\
\text { Industry }\end{array}$ & $\begin{array}{c}\text { Kebutuhan } \\
\text { garam industry/ } \\
\text { Salt Needs of } \\
\text { Industry }\end{array}$ \\
\hline 1 & RMSPE & 2.82 & 0.49 & 0.65 & 0.27 \\
2 & AME & 0.27 & -0.29 & -0.27 & 0.16 \\
3 & AVE & 0.63 & -0.63 & -0.24 & 0.31 \\
\hline
\end{tabular}

Sumber : data primer diolah, 2013

Source : primary data processed, 2013 
persen per tahun (diolah dari data Kemenperin, 2012)

23. Tingkat pertumbuhan kebutuhan garam industri untuk industri chlor alkali 1,22 persen per tahun (diolah dari data Kemenperin, 2012)

24. Tingkat pertumbuhan kebutuhan garam industri untuk industri pengeboran minyak
0,3 persen per tahun (diolah dari data Kemenperin, 2012)

25. Tingkat pertumbuhan kebutuhan garam industri untuk industri lainnya 2,78 persen per tahun (diolah dari data Kemenperin, 2012)

26. Persentase penyusutan surplus garam dari tahun lalu adalah sebesar 25 persen (Kemenperin, 2011)

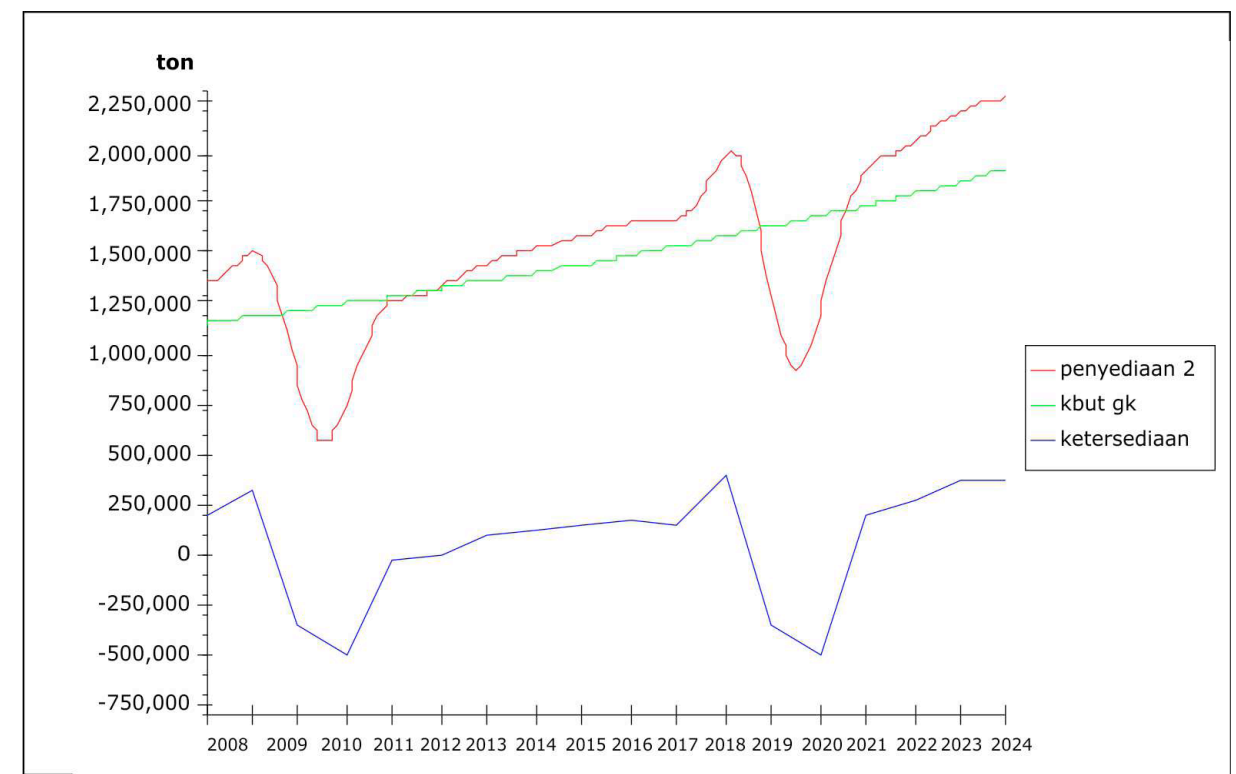

Gambar 3. Ketersediaan Garam Konsumsi Sebelum ada Kebijakan, Tahun 2008-2025. Figure 3. Salt Availability for Consumption Before Policy Implementation, Year 2008-2025.

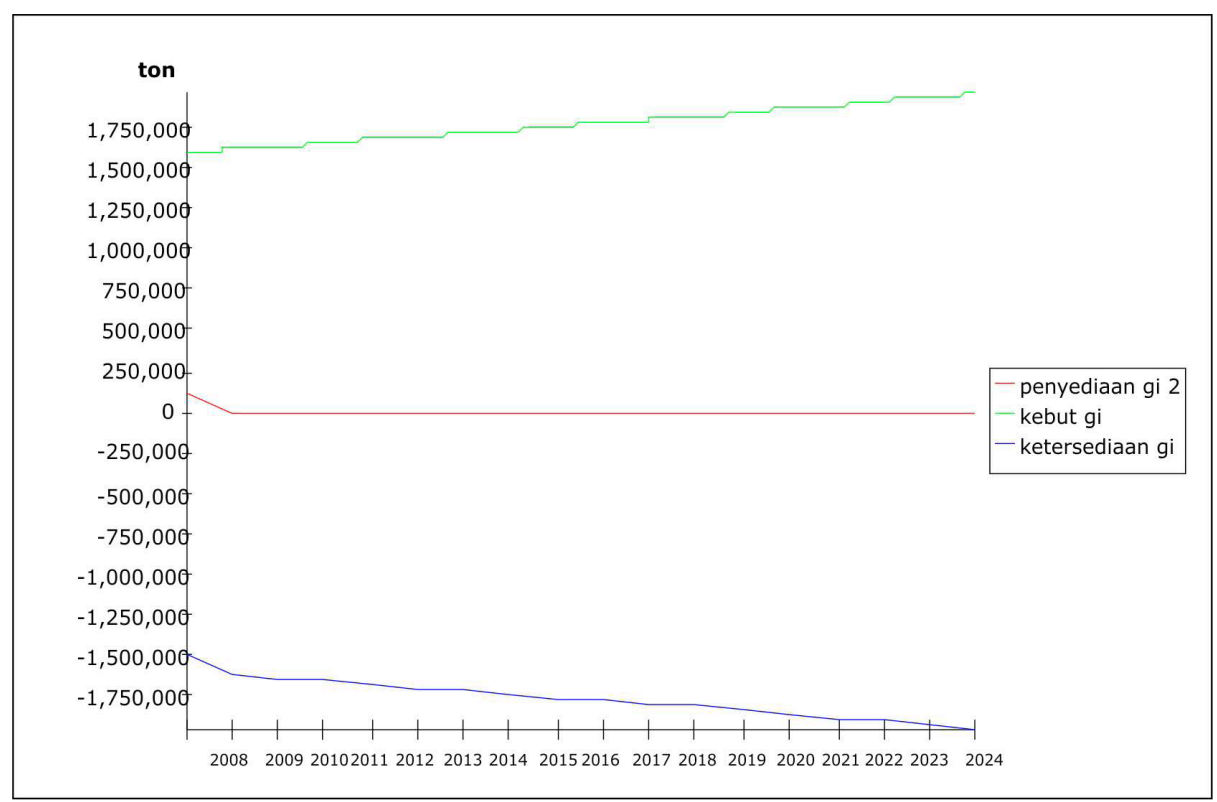

Gambar 4. Ketersediaan Garam Industri Sebelum ada Kebijakan, Tahun 2008-2025 Figure 4. Salt Availability for Industry Before Policy Implementation, Year 2008-2025 


\section{Validasi Model}

Validasi struktur dilakukan langsung oleh perangkat lunak. Dari hasil pengujian tersebut, tidak ditemukan inkonsistensi dalam penggunaan dimensi. Sedangkan hasil uji validitas kinerja model dengan menggunakan RMSPE, AME dan AVE membandingkan hasil kinerja model dengan data empiris yang ada, hasilnya menunjukkan penyimpangan tidak melebihi 5 persen. Sehingga model valid baik secara struktur maupun kinerja model.

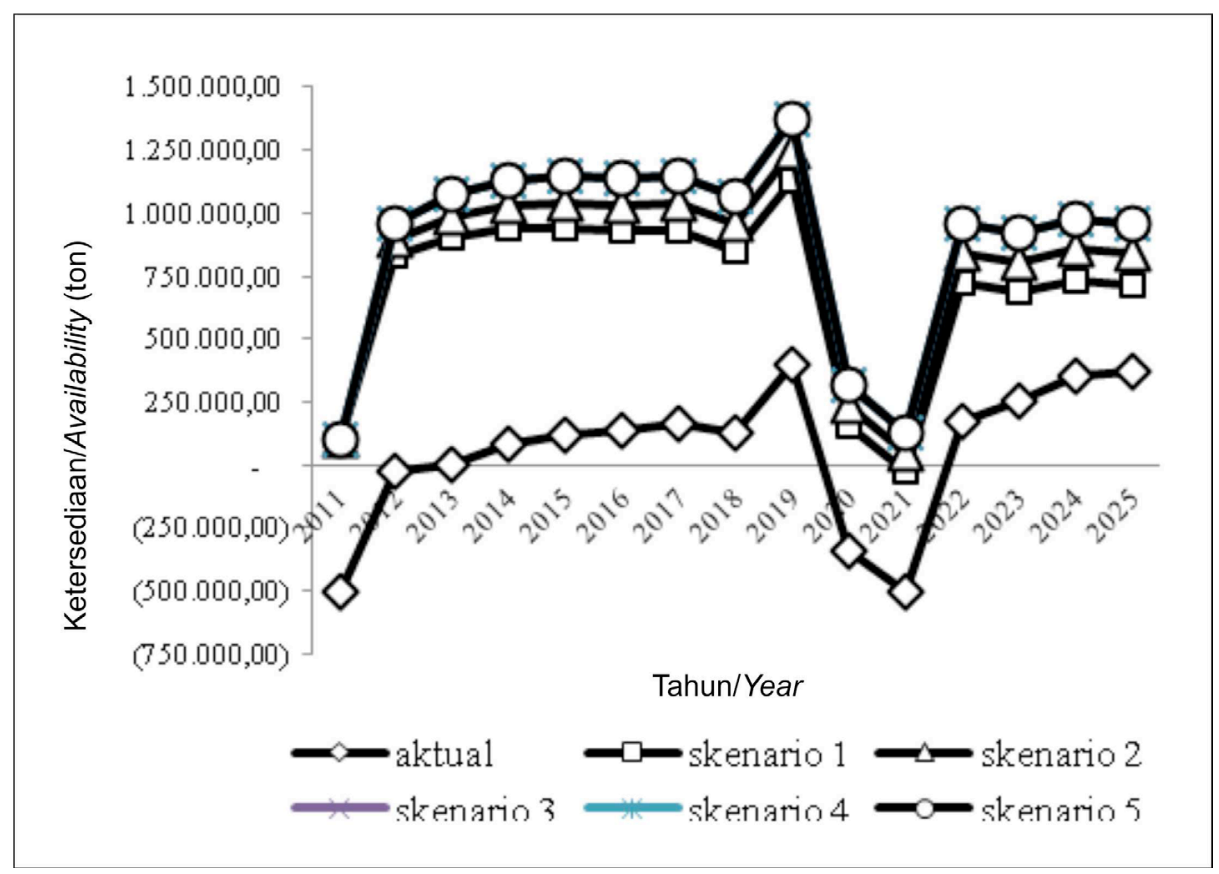

Gambar 5. Perbandingan Ketersediaan Garam Konsumsi Aktual dan Setelah ada Kebijakan Swasembada.

Figure 5. Comparison of the Salt Availability for Consumption Actual and After the Policy Implementation.

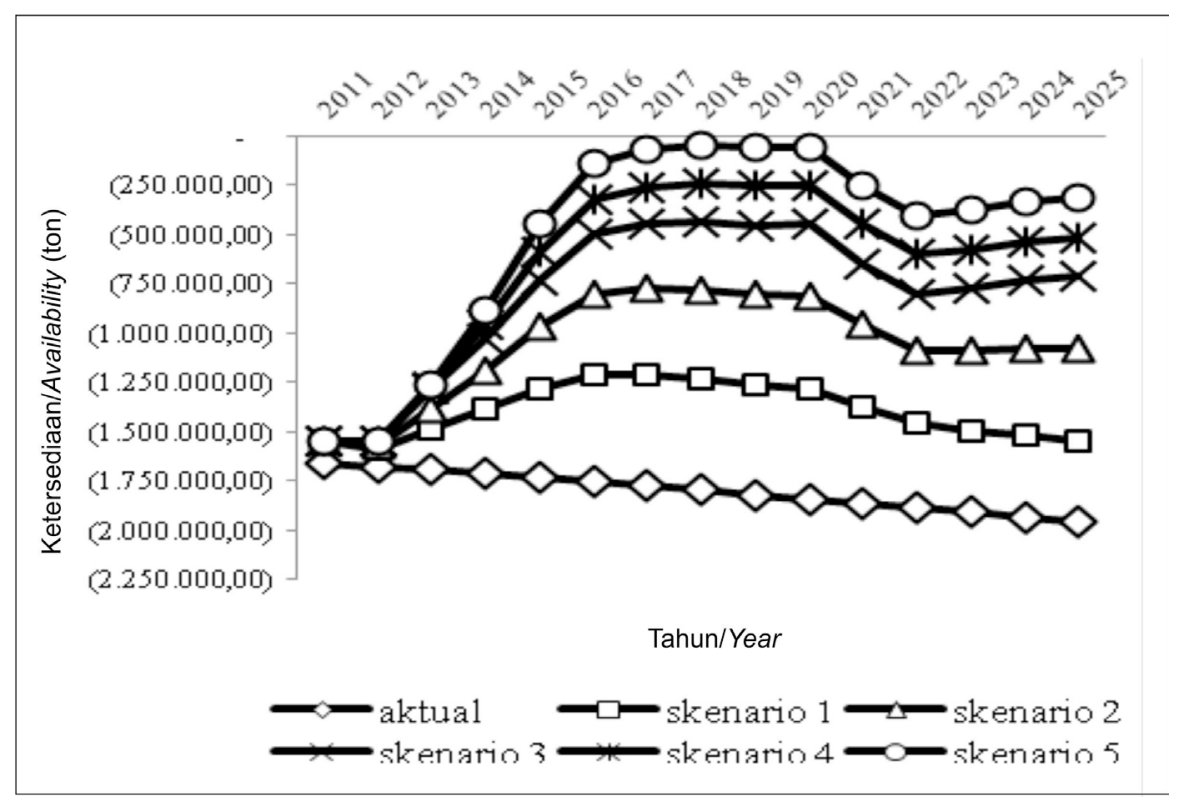

Gambar 6. Perbandingan Ketersediaan Garam Industri Aktual dan Setelah Ada Kebijakan Swasembada.

Figure 6. Comparison of the Salt Availability for Industry Actual and After the Policy Implementation. 
Analisis Ketersediaan Garam Nasional Sebelum Ada Kebijakan (Tanpa Kebijakan)

Simulasi yang dilakukan terhadap penyediaan garam konsumsi menunjukkan pola oscillation. Pola ini dipengaruhi oleh jumlah hari panen. Jumlah hari panen berdasarkan data time series tahun 1997-2012 menunjukkan kecenderungan terjadi cuaca ekstrim yang berulang dalam per 10 tahun (periode tahun 2000 dan tahun 2010). Sedangkan simulasi terhadap kebutuhan garam baik garam konsumsi maupun garam industri menunjukkan pola exponential growth.

Selama periode simulasi, ketersediaan garam konsumsi berfluktuasi (Gambar 3). Ketersediaan menunjukkan nilai negatif pada saat tahun 2010, 2011, 2012, 2020 dan 2021 (kondisi cuaca ekstrim). Di luar tahun tersebut, Indonesia sudah dapat mencapai swasembada garam konsumsi. Sedangkan ketersediaan garam industri, dari hasil simulasi yang dilakukan belum dapat mencapai swasembada garam industri (Gambar 4).

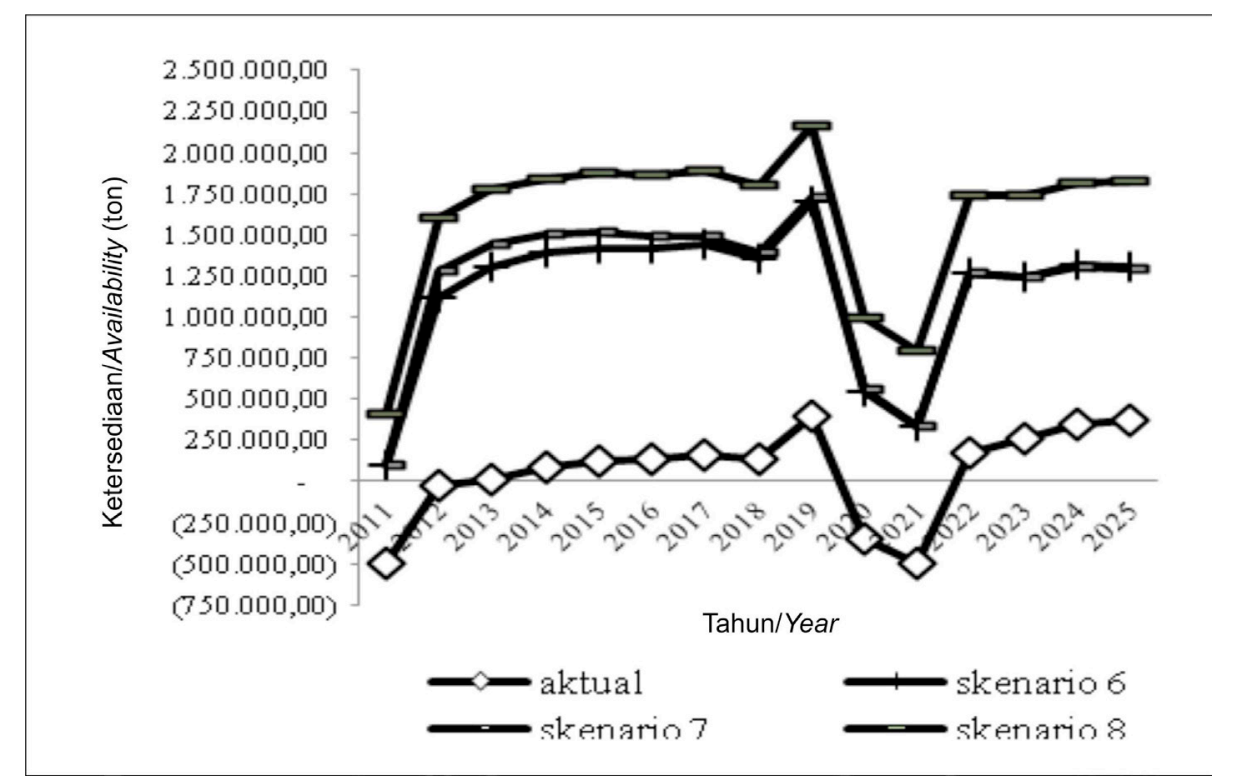

Gambar 7. Perbandingan Ketersediaan Garam Konsumsi Pada Skenario Kebijakan Alternatif. Figure 7. Comparison of the Salt Availability for Consumption in the Policy Scenario Alternative.

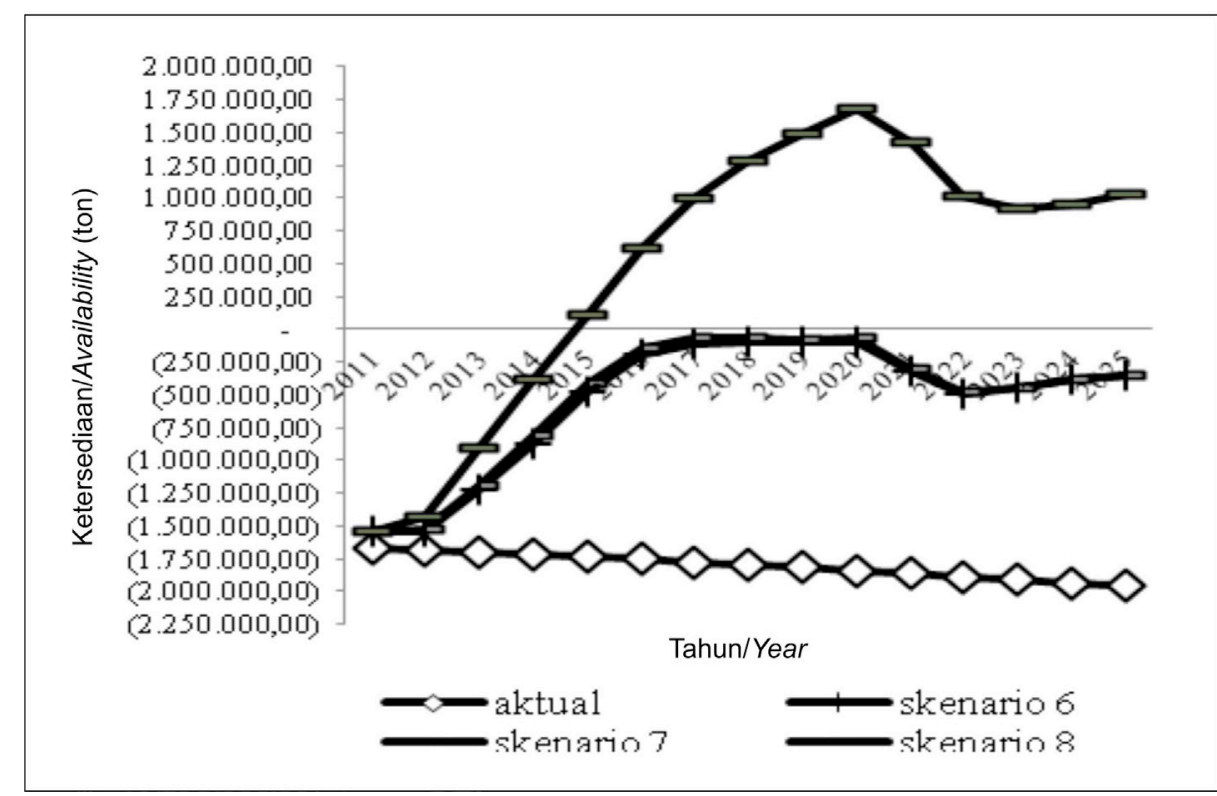

Gambar 8. Perbandingan Ketersediaan Garam Industri Pada Skenario Kebijakan Alternatif. Figure 8. Comparison of the Salt Availability for Industry in the Policy Scenario Alternative. 
Sehingga keberlanjutan swasembada garam nasional pada kondisi tanpa ada kebijakan pemerintah tidak dapat tercapai.

\section{Analisis Ketersediaan Garam Nasional Setelah Ada Kebijakan}

Kebijakan swasembada garam nasional menargetkan tercapainya swasembada garam konsumsi di tahun 2012, dan swasembada garam industri di tahun 2015. Sedangkan penelitian ini mengukur ketercapaian swasembada tidak hanya pada satu titik pencapaian, melainkan menitikberatkan pada keberlanjutan pencapaian swasembada.

Simulasi setelah ada kebijakan swasembada garam nasional dituangkan dalam skenario 1 hingga 5 (Gambar 6 dan Gambar 7). Dari hasil simulasi menunjukkan bahwa kelima skenario kebijakan swasembada telah berhasil mengantarkan Indonesia mencapai swasembada garam konsumsi di tahun 2012 (Gambar 5). Sedangkan keberlanjutan swasembada garam konsumsi selama periode simulasi dapat tercapai jika melakukan skenario 2,3,4 dan 5. Artinya, Indonesia dapat mencapai swasembada garam konsumsi secara berkelanjutan ketika pelaksanaan kebijakan swasembada garam nasional sedikitnya mencapai 80 persen dari indikator pencapaian atau dengan kata lain swasembada garam konsumsi secara berkelanjutan dapat tercapai jika terjadi produktivitas lahan tambak PUGAR ditingkatkan menjadi 79.2 ton per hektar.

Gambar 6 menjelaskan bahwa kebijakan swasembada garam nasional belum dapat mencapai target swasembada garam industri di tahun 2015, bahkan hingga akhir periode simulasi ketersediaan garam industri masih menunjukkan angka negatif. Artinya, peningkatan penyediaan garam industri melalui kebijakan ekstensifikasi lahan tambak garam dan peningkatan produktivitas lahan tambak belum mampu mengimbangi besarnya pertumbuhan kebutuhan garam industri.

\section{Skenario Kebijakan Alternatif untuk Pencapaian Keberlanjutan Swasembada Garam Nasional}

Dari hasil simulasi sebelumnya, kebijakan swasembada garam nasional baru dapat mengantarkan Indonesia mencapai swasembada garam konsumsi berkelanjutan. Untuk itu pada bagian ini disusun beberapa kebijakan alternatif yang bertujuan untuk meningkatkan ketersediaan sehingga swasembada garam nasional dapat tercapai bukan hanya bagi garam konsumsi, namun juga bagi garam industri.

Hasil simulasi kebijakan alternatif menunjukkan skenario 6 dan 7 telah mampu mengantarkan Indonesia mencapai swasembada garam konsumsi berkelanjutan namun tidak pada swasembada garam industri (Gambar 7 dan Gambar 8). Sedangkan simulasi pada skenario 8, berhasil mengantarkan Indonesia mencapai swasembada garam konsumsi secara berkelanjutan dan mencapai swasembada garam industri berkelanjutan dimulai pada tahun 2015 . Skenario ini merupakan kombinasi kebijakan dari sisi peningkatan penyediaan (dari sisi kuantitas dan kualitas) dan pengurangan konsumsi. Kebijakan di sisi penyediaan meliputi (1) peningkatan produktivitas pada lahan PUGAR menjadi sebesar 97 ton per hektar, (2) seluruh garam rakyat terintervensi PUGAR (subsidi input), (3) kebijakan ekstensifikasi lahan, (3) peningkatan produktivitas lahan ekstensifikasi hingga mencapai 100 ton per hektar, (4) peningkatan kualitas garam yang dihasilkan oleh seluruh garam rakyat sehingga memenuhi kriteria garam industri. Adapun kebijakan dari sisi konsumsi adalah pengurangan jumlah konsumsi garam rumah tangga dengan mengikuti rekomendasi salt intake dari WHO (2007) yaitu sebesar 5 gram per kapita per hari Kebijakan peningkatan kualitas garam rakyat merupakan kebijakan kunci sehingga Indonesia dapat mencapai swasembada garam berkelanjutan baik konsumsi maupun industri.

\section{KESIMPULAN DAN IMPLIKASI KEBIJAKAN}

1. Model sistem ketersediaan garam nasional yang dibangun dinyatakan valid baik melalui uji struktur maupun uji kinerja model. Hasil simulasi terhadap model tersebut menunjukkan bahwa sebelum ada kebijakan swasembada, Indonesia belum dapat mencapai swasembada garam konsumsi dan swasembada garam industri.

2. Kebijakan swasembada garam nasional berdampak pada pencapaian swasembada garam konsumsi secara berkelanjutan. Simulasi terhadap 5 skenario menunjukkan bahwa swasembada garam konsumsi secara berkelanjutan sudah dapat tercapai setidaknya apabila 80 persen dari 
indikator kebijakan tercapai. Sementara pada garam industri, swasembada belum dapat tercapai.

3. Kebijakan alternatif yang disusun dapat mengantarkan Indonesia mencapai swasembada garam konsumsi secara berkelanjutan selama periode simulasi. Sedangkan swasembada garam industri yang berkelanjutan (dimulai tahun 2015) dapat tercapai apabila skenario 8 diterapkan, yaitu dengan melakukan kebijakan kunci berupa peningkatan kualitas garam rakyat sehingga memenuhi kriteria kebutuhan industri.

\section{SARAN}

1. Peningkatan kualitas merupakan solusi kunci setelah peningkatan kuantitas dalam permasalahan ketersediaan garam nasional. Dalam hal peningkatan kualitas ini, perlu dilakukan penelitian lebih lanjut mengenai teknik peningkatan kualitas garam rakyat. Terkait hal tersebut, pemerintah sebagai pengambil kebijakan disarankan melakukan diseminasi dari temuan-temuan teknologi terbaru yang dapat meningkatkan kualitas seperti teknologi geomembran.

2. Pengembangan model dengan memperhitungkan kualitas dan biaya dapat membantu memberikan prioritas kebijakan bukan hanya dari sisi teknis namun juga dari sisi anggaran.

3. Ketersediaan data yang valid merupakan hal yang vital dalam mengukur ketercapaian swasembada. Untuk itu pemerintah sebagai pengambil kebijakan disarankan menyediakan data yang representatif dengan kondisi di lapang terkait besarnya produksi garam yang diklasifikasikan berdasarkan kualitasnya, data stok garam di akhir tahun, kebutuhan garam berdasarkan pemanfaatannya, informasi mengenai data-data klimatologi dan meteorologi wilayah sentra garam.

\section{DAFTAR PUSTAKA}

Aligori, A. 2013. Efisiensi Produksi Usaha Garam Rakyat di Kabupaten Indramayu [tesis]. Bogor (ID) : IPB.
Badan Penelitian dan Pengembangan Kelautan dan Perikanan Kementerian Kelautan dan Perikanan. 2012. Prosiding Seminar: Strategi Swasembada Garam. Bogor: Kementerian Kelautan dan Perikanan.

Departemen Perindustrian. 2009. Peta Panduan Pengembangan Klaster Industri Prioritas Industri Kecil dan Menengah Tahun 2010-2014. Jakarta: Departemen Perindustrian.

Georgiadis, P. 2004. A System Dynamics Modeling Framework for the Strategic Supply Chain Management of Food Chains. Journal of Food Engineering. 70: 351-364.

Harmini, R.W. Asmarantaka, dan J. Atmakusuma. 2011. Model Dinamis Sistem Ketersediaan Daging Sapi Nasional. Jurnal Ekonomi Pembangunan. 12(1): 128-146.

Irawan. 2005. Analisis Ketersediaan Beras Nasional : Suatu Kajian Simulasi Pendekatan Sistem Dinamis. Prosiding Multifungsi Pertanian.

Kementerian Koordinasi Bidang Perekonomian. 2012. Kebijakan Swasembada Garam Nasional [Bahan Presentasi]. Rapat Koordinasi Teknis Swasembada Garam Nasional. 2012 Feb 23. Semarang.

Kementerian Perindustrian. 2012. Data Produksi, Kebutuhan dan Impor Garam tahun 2001-2011. Kementerian Perindustrian.

Kementerian Perindustrian. 2013. Data Produksi, Kebutuhan dan Impor Garam tahun 2001-2012. Kementerian Perindustrian.

Kementerian Perindustrian. 2011. Laporan Antara Penyusunan Business Plan Pengembangan Industri Garam. Kementerian Perindustrian.

Kementerian Kelautan dan Perikanan. 2012. Industrialisasi Usaha Garam Rakyat [Bahan Presentasi] Direktorat Jenderal Kelautan, Pesisir, dan Pulau-Pulau Kecil Kementerian Kelautan Dan Perikanan. Jakarta.

Nurmalina, R. 2007. Model Neraca Ketersediaan Beras yang Berkelanjutan untuk mendukung Ketahanan Pangan Nasional [disertasi]. Bogor: Institusi Pertanian Bogor.

PT. Garam. 2013. Data Produksi PT Garam. Surabaya.

Rachman, A. 2011. Evaluasi Kinerja Usaha Petani Garam Rakyat Studi Kasus di Kabupaten Bima, Nusa Tenggara Barat. [tesis]. Bogor: Institusi Pertanian Bogor. 
Ristono, A. 2011. Pemodelan Sistem. Yogyakarta: Graha IImu.

Somantri, A.S. dan Machfud. 2006. Analisis Sistem Dinamik untuk Kebijakan Penyediaan Ubi Kayu (Studi Kasus di Kabupaten Bogor). Buletin Teknologi Pasca Panen Pertanian. (2): $36-48$.

Somantri, A.S. dan R. Thahir. 2007. Analisis Sistem Dinamik Ketersediaan Beras di Merauke dalam rangka menuju Lumbung Padi bagi Kawasan Timur Indonesia. Buletin Teknologi Pascapanen Pertanian. 3:
Wirjodirdjo, B. 2004. Skenario Kebijakan Pengembangan Pergaraman Nasional Dalam Usaha Mengurangi Ketergantungan Luar Negeri: Suatu Penghampiran Model Sistem Dinamik. Jurnal Eksekutif. 1:

World Health Organization. 2007. Reducing Salt Intake in Populations : Report of a WHO Forum and Technical Meeting. Paris, France: WHO 